


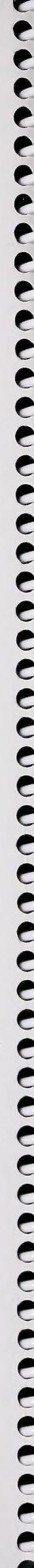




\title{
Gillett's Checkerspot in the Southern Headwaters at Risk (SHARP) Project Area
}

\author{
Norbert G. Kondla
}

Alberta Species at Risk Report No. 96

February 2005

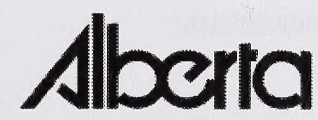

SUSTAINABLE RESOURCE DEVELOPMENT

Fish \& Wildlife 
Publication No. I/210

ISBN: 0-7785-4050-2 (Printed Edition)

0-7785-4051-0 (On-line Edition)

ISSN: 1496-7219 (Printed Edition)

ISSN: 1496-7146 (On-line Edition)

Cover photograph: Norbert Kondla, Female Gillett's Checkerspot on Lodgepole Pine.

For copies of this report, contact:

Information Centre- Publications

Alberta Environment/Alberta Sustainable Resource Development

Main Floor, Great West Life Building

9920- 108 Street

Edmonton, Alberta, Canada T5K 2M4

Telephone: (780) 422-2079

OR

Visit our web site at:

http://www3.gov.ab.ca/srd/fw/speciesatrisk/

This publication may be cited as:

Kondla, N.G. 2005. Gillett's checkerspot in the southern headwaters at risk (SHARP) project area, Alberta. Sustainable Resource Development, Fish and Wildlife Division, Alberta Species at Risk Report No. 96, Edmonton, AB. 29pp. 


\section{ACKNOWLEDGEMENTS}

Special thanks to Richard Quinlan and David Poll for making this project possible. A number of people kindly shared information: Andrew Colley, Ken Davenport, Diane Debinski, Cliff Ferris, Ian Gardiner, Steve Kohler, Ted Pike, Harold Pinel, Ernest Williams, Chris Schmidt, Cyndi Smith, Reginald Webster, Ernest Williams. Special thanks to A. Colley, D. Debinski and E. Williams for taking the time to review a draft of this report.

\section{EXECUTIVE SUMMARY}

Gillett's Checkerspot is a colorful and distinctive butterfly that has a very small global range and a global conservation status rank of imperiled/vulnerable. In Canada its distribution is limited to less than $0.2 \%$ of the land base. Within this small geographic area it is present in only a small subset of habitats and is further dependent for its survival on the presence of bracted honeysuckle plants growing in sunny locations near trees that are used for overnight roosting and mating. Only 30 populations are known for the species in Alberta, despite extensive historical field work and intensive searching in 2004. The species is therefore a subject of conservation concern and warrants affirmative management attention.

The species is relatively well known with respect to its' biology and ecology. Available information is summarized. Differences between USA and Alberta populations are discussed. The ecology of the species renders it amenable to integration with economic activity. It can be accommodated without significant expense or impact on other natural resource uses. In some cases, forest canopy removal associated with development can be a positive factor for the species but in the past this has been an accidental byproduct of such activity. It is recommended that an informed planning and design approach be adopted as a preferable management approach. Brief strategic and operational guidelines are recommended. 


\section{Table of Contents}

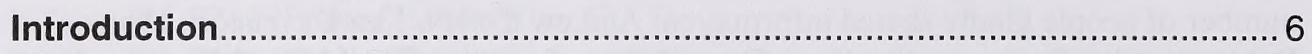

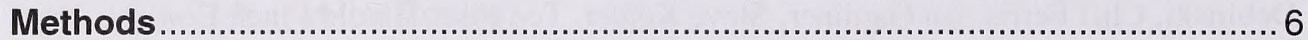

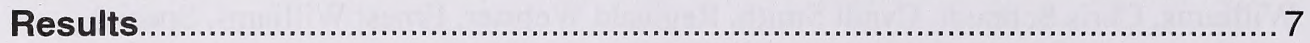

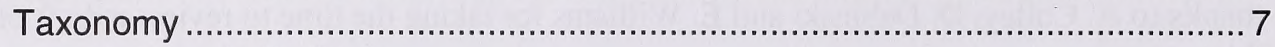

Description of Life Stages ......................................................................... 7

Ecology and Habitat............................................................................... 10

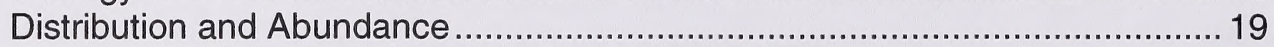

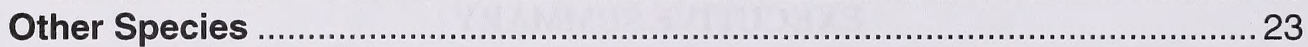

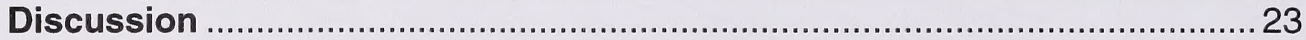

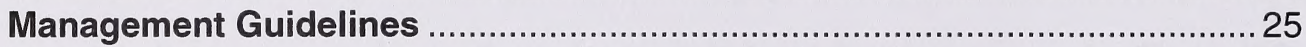

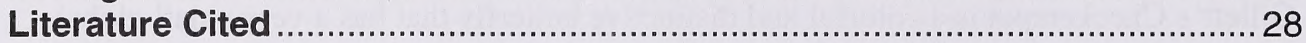

\section{Table of Figures}

Figure 1. In situ egg masses of Gillett's Checkerspot........................................ 8

Figure 2. Larvae of Gillett's Checkerspot..................................................... 9

Figure 3. Pupa of Gillett's Checkerspot...................................................... 9

Figure 4. Mix of non-hatched eggs, empty egg casings and young larvae.......... 9

Figure 5. Late instar larva....................................................................... 10

Figure 6. Female laying eggs on underside of honeysuckle leaf. .................... 11

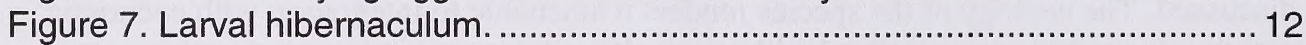

Figure 8. Male taking salt and water on damp road surface........................... 13

Figure 9. Breeding habitat of Gillett's Checkerspot at the edge of a cutblock

harvested the previous year in the Whitney Creek area........................... 16

Figure 10. Breeding habitat in an older regenerating cutblock near Beavermines Lake

Figure 11. Natural breeding habitat in a small groundwater discharge site in the

upper Carbondale River valley.

Figure 12. Natural breeding habitat in a fen/bog complex adjacent a valley bottom stream of the Livingstone River valley.

Figure 13. Breeding habitat at edge of sedge fen in upper Oldman River valley.18

Figure 14. Distribution of Gillett's Checkerspot in the SHARP area...................2 20

Figure 15. Oblique view of the area west of Beavermines Lake........................21

Figure 16. Aerial photograph (1982) of the area west of Beavermines Lake......21 


\section{Introduction}

This report follows on an overview butterfly conservation assessment for the SHARP (Southern Headwaters At Risk Project) area (Kondla 2004). The Gillett's Checkerspot (see Zirlin 2001 re. spelling of common name) was selected for more detailed assessment because the biology of the species is well known in comparison to other species in the area, the species is relatively easy to find in areas where it is present and it has a global conservation status rank of S2S3 (imperiled/vulnerable). Conservation concern with respect to this species has been previously articulated by Debinski (1994), Guppy et al. (1994), Kondla et al. (2000), Williams et al. (1984) and Williams (1988). The report summarizes the results of a brief field survey and review of pertinent literature. It also includes preliminary management recommendations for Gillettt's Checkerspot.

\section{Methods}

Existing information was largely gleaned from my personal files and library of butterfly literature. I also conducted web searches, posted requests for information on two internet butterfly discussion groups and consulted directly with other biologists and naturalists who have field experience with Gillett's Checkerspot. Historical occurrence records were retrieved via web access to the Canadian Biodiversity Information Facility.

I summarized readily available published and unpublished information on sites/areas where the butterfly has been previously found within the SHARP area, which includes the great majority of historical records for Alberta. I consulted published literature on salient biological information, especially larval food plant and previously reported habitats.

I then conducted road transects, at slow speed to watch for possible locations where the butterfly may be present. The visual cues were presence of bracted honeysuckle Lonicera involucrata (larval food plant), which is normally easy to see from a distance, in areas supporting scattered coniferous trees or forest with an open canopy structure. I also examined some sites with Lonicera present in dense forest to confirm existing information that they do not breed in such habitats. Candidate areas that looked promising (and many that did not) were then examined on foot. When weather was suitable for butterfly flight activity I searched for both adults and egg masses on the honeysuckle. When weather was not suitable for adult flight, I searched for egg masses. I also noted other butterfly species in areas examined, especially other species ranked S1 to S3 by Alberta Natural History Information Centre.

I paid special attention to landscape position of occupied sites and primary habitat attributes to compare with previously published information on the species. Primary field work for this project was conducted from 6 to 13 July 2004. Searches were conducted in Waterton Lakes National Park from 13 to 15 July (20 sites/areas) and some additional volunteer work was conducted on 26 July ( 3 areas). More than 75 sites were examined in the SHARP area. Details of numerous sites examined, without honeysuckle or the target butterfly present, were not recorded. The primary purpose of the field work were to 
examine as much of the landscape as possible within available time to assess the status of the species in relation to information from other areas.

\section{Results}

A significant literature on the biology and ecology of Gillett's Checkerspot is available, primarily from research in the USA. This report has borrowed substantially from said literature, although specific citations have been limited to enhance readability of the report. Papers of particular note include: Bowers and Williams (1995), Debinski (1994), Debinski et al. (1999), Holdren and Ehrlich (1981), Williams (1981), Williams (1988), Williams (1990), Williams (2001), Williams and Bowers (1987), Williams et al. (1984).

\section{$\underline{\text { Taxonomy }}$}

Unlike many other North American butterfly species, the taxonomy of E. gillettii is uncomplicated at the species level. There are no described subspecies. Genus level taxonomy however, is open to two different interpretations. I use the most popular interpretation, on this continent, of including the species in the broader genus concept of Euphydryas. Another equally correct option is to treat gillettii as a member of the more narrowly defined genus Hypodryas (eg. Ferris and Brown 1980, Higgins 1978, Miller and Brown 1981). One additional contemporary arrangement in North America is to recognize Hypodryas as a subgenus of Euphydryas. However, it should be noted that the Higgins classification appears to be in use in other geographic areas (eg. Tolman 1997). This matter has also recently been commented on by Guppy and Shepard (2001). Information on genetics and checkerspot taxonomy at the genus level can be found in Brussard et al. (1985) and Zimmermann et al. (2000).

\section{$\underline{\text { Description of Life Stages }}$}

Gillett's Checkerspot has a typical lepidopteran life cycle of complete metamorphosis from egg to larva (caterpillar) to chrysalis (pupa) to adult. Comstock (1940) provided initial information on the early stages and subsequently Williams et al. (1984) have provided a fuller account.

The following summary of early stages is from Williams et al. (1984):

Egg: nearly spherical, with rounded base and sides sloping in to flattened top; approximately 22 longitudinal ridges with irregular pitting on base and horizontal striations between ridges; egg diameter average $0.78 \mathrm{~mm}$ and height average $0.86 \mathrm{~mm}$; eggs are pale straw-yellow when laid and darken with age to red-brown; becoming bluegrey shortly before hatching due to formation of a dark head capsule beneath the translucent egg shell. 
Figure 1. In situ egg masses of Gillett's Checkerspot. Note that the tan-brown colored eggs are older than the yellow eggs deposited later. N. Kondla photo.

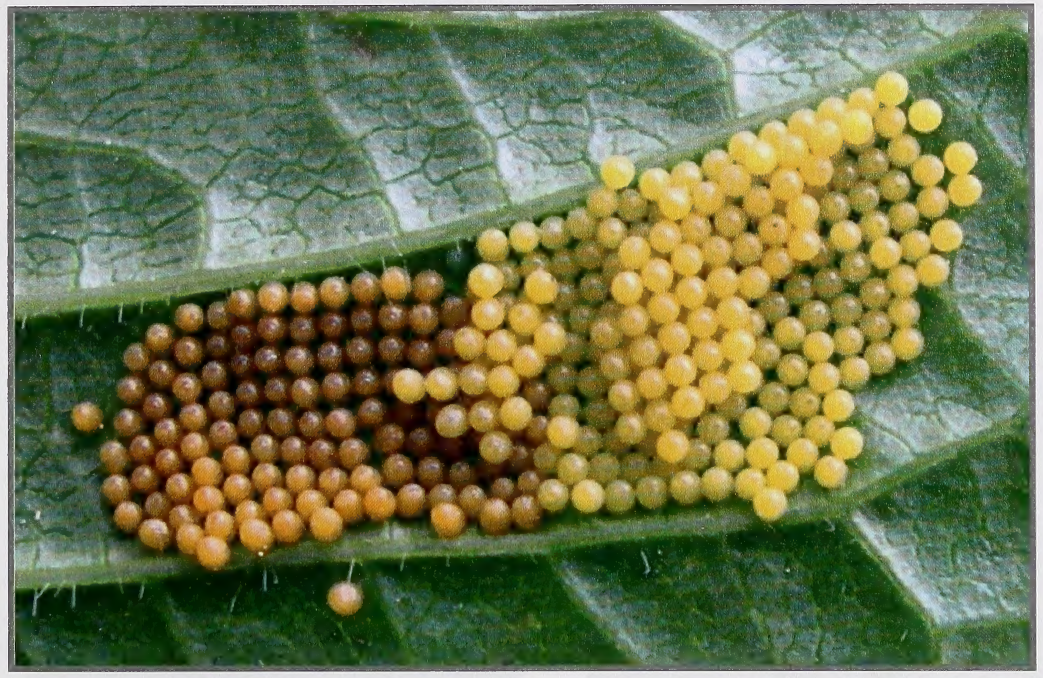

First instar larva: blackish brown head and pale body spotted with brown; body length 3$4 \mathrm{~mm}$.

Second instar larva: body developing typical banding pattern of later instars; dorsal band pale yellow, dorsolateral band brown, lateral band dull white, ventrolateral band light brown and ventral band cream colored; legs remain brown and branching spines develop from papillae; body length 4-6 $\mathrm{mm}$.

Third instar larva: head black and deeper colors to banding; shafts of spines mostly darker; legs black; body length 5-9 $\mathrm{mm}$.

Fourth instar larva: further development of banding pattern; dorsal band lemon yellow, dorsolateral band blackish brown, ventrolateral band brown, ventral band pale yellow with brown mid-ventral stripe; shafts of all spines black; body length 9-13 mm.

Fifth instar larva: as fourth instar but dorsal stripe bright lemon yellow, dorsolateral band black and spines jet black. Sixth instar larva is as previous but sharper banding contrast and midventral line blackish brown. Body length of fifth instar ranges from 12-18 mm and of sixth instar ranges from $15-30 \mathrm{~mm}$.

Pupa: cream colored with black markings; seven orange warts per abdominal segment; pupal length average $16 \mathrm{~mm}$.

Adults have a unique appearance that renders them easy to identify in the field. There is no other butterfly in Alberta that has the characteristic reddish-orange postmedial band on both dorsal wing surfaces. Dorsal wing surfaces are a mix of 
Figure 2. Larvae of Gillett's Checkerspot. E. Williams photo.

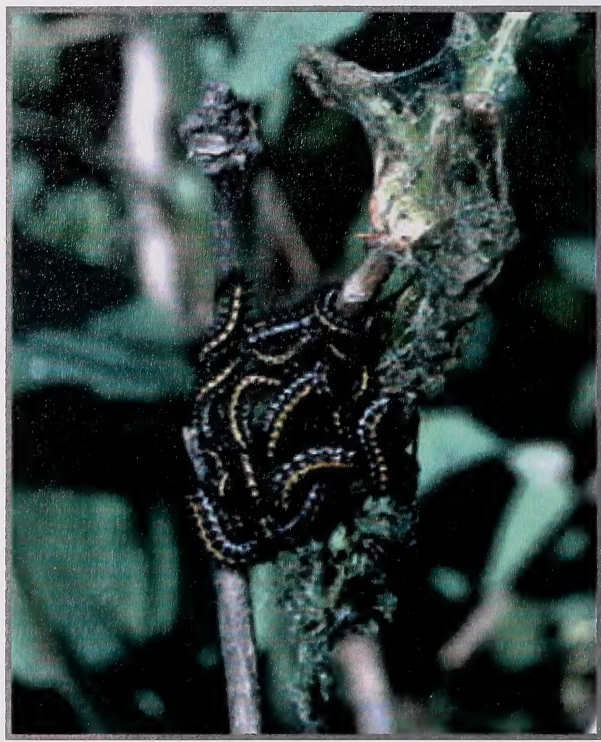

Figure 3. Pupa of Gillett's Checkerspot. E. Williams photo.

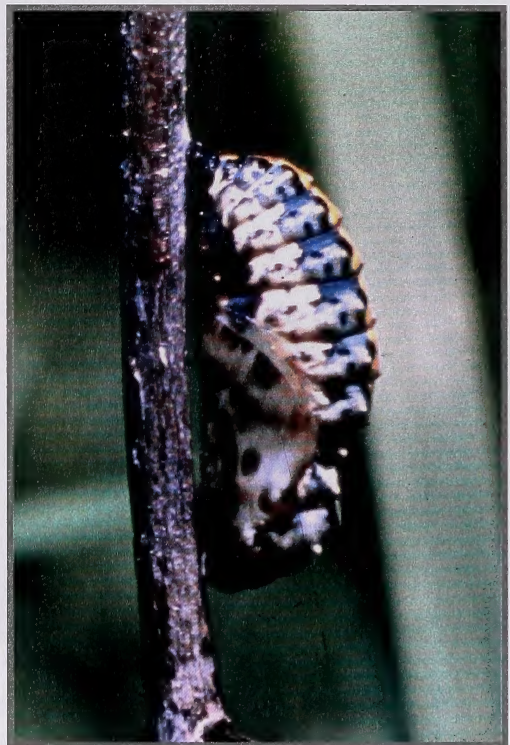

Figure 4. Mix of non-hatched eggs, empty egg casings and young larvae. I. Gardiner photo.

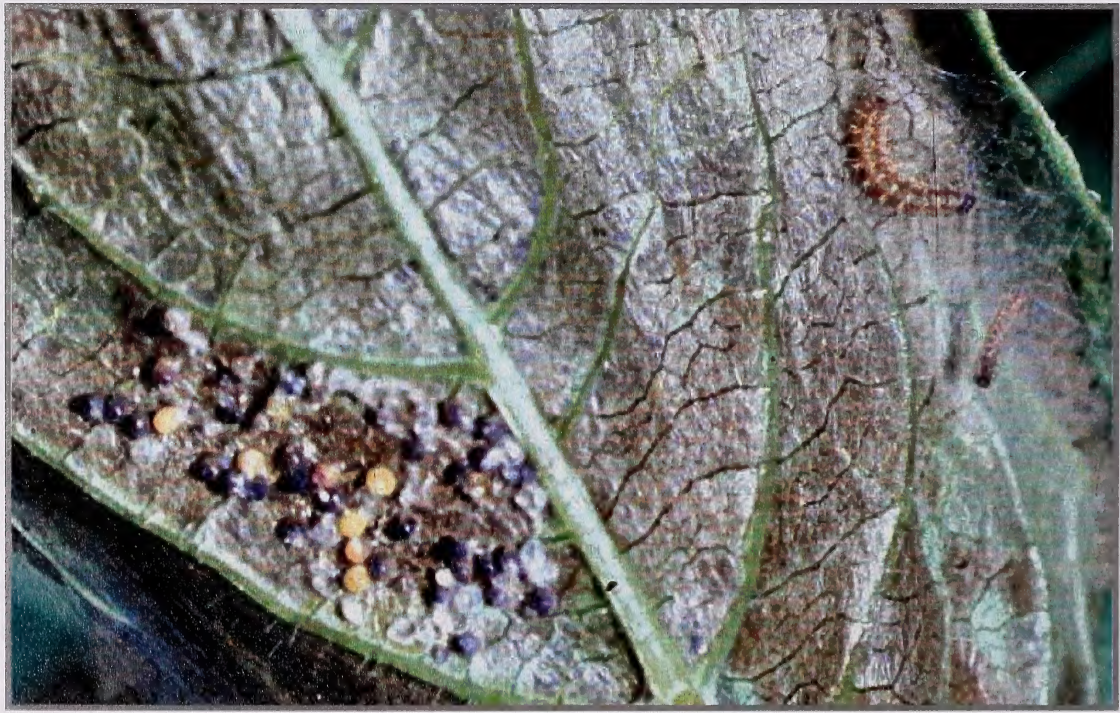

white, black and reddish-orange. The dorsal appearance is of a predominantly dark butterfly while the ventral appearance is a predominant mix of white and reddish-orange. Males have a wingspan in the order of $4 \mathrm{~cm}$ and females are usually larger, with a wingspan in the order of 4.5 to $5 \mathrm{~cm}$. The head, thorax and abdomen are black. The palpi and legs are reddish-orange. 
Figure 5. Late instar larva. E. Williams photo.

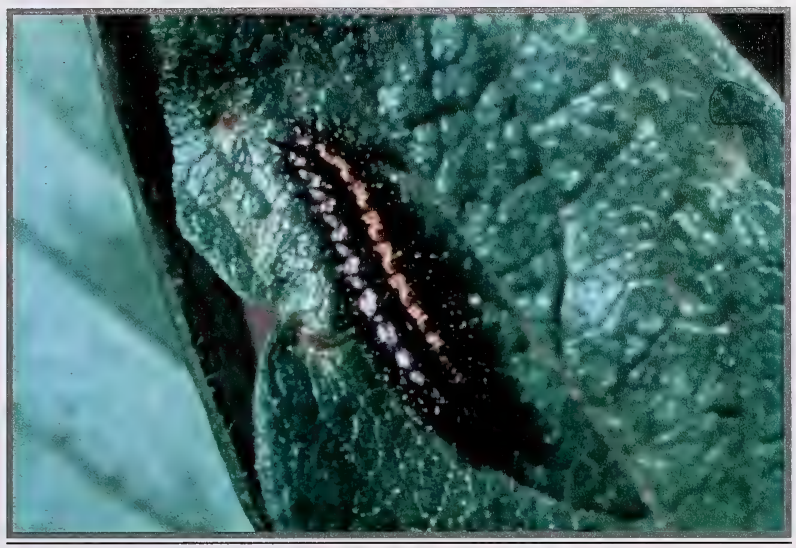

\section{Ecology and Habitat}

The following synopsis has been largely extracted from Williams et al. (1988) and this source is not repeatedly cited in order to improve readability. This source also includes information from Williams (1981).

Females lay eggs on bracted honeysuckle (Lonicera involucrata) as the predominant larval food plant. In one Wyoming study population a small percentage (1 to $4 \%$ ) of egg masses were found on Valeriana occidentalis. Williams and Bowers (1987) found that larval survival and growth on both host plants was statistically equivalent. Bracted honeysuckle has a continental distribution that far exceeds the small range of Gillett's Checkerspot. Larval foodplant availability is thus not a plausible explanation for the range boundaries of this butterfly. Williams (1988) also reported one population ovipositing on Pedicularis and another species of Lonicera. Only bracted honeysuckle has been confirmed as a larval food plant in Alberta.

The leaves of the honeysuckle are large enough to allow the females to move to the underside of the leaves, which is where the eggs are deposited. Egg laying mostly occurs in the late morning. When a female has found a suitable honeysuckle plant it can take more than two hours before an agreeable leaf and location on a leaf is selected for oviposition. Wings are normally held open while laying eggs (Figure 5). In a Wyoming population egg clusters ranged in size from 23 to 310 eggs, with a mean of 146 eggs per cluster. Leaves chosen for oviposition are large and at or near the top of honeysuckle plants. Prime leaves often receive more than one egg cluster. Females oviposit at an average rate of 3.8 eggs per minute, thus needing 38 minutes to deposit an average size egg cluster.

Empirical data from a Wyoming population shows that eggs are preferentially placed on leaves which face the southeast and thus the morning sun. Since the eggs are laid on the underside, this places the ovipositing female in shade and presumably reduces predation frequency while ovipositing. The combination of egg laying on southeast oriented leaves 
at higher locations on honeysuckle plants provides a better thermal regime and significantly faster egg hatching on these microsites. Eggs have been found to hatch from 18 to 45 days after laying; dependent on various scale climatic variables.

A variable percentage of eggs become detached through natural process prior to hatching, however most clusters lose few eggs this way. Predators of eggs and larvae that have been reported are: erythraid mites, myrid bugs, beetle larvae, parasitic wasps and browsing mammals, including moose and cattle. Prediapause larval mortality is high; at least $80 \%$ of prediapause larvae disappeared in one monitored population. Newly emerged larvae feed partially on the empty egg shells and within one day move to the upperside of the leaf where they form a communal feeding web.

\section{Figure 6. Female laying eggs on underside of honeysuckle leaf. $\mathbf{N}$. Kondla photo}

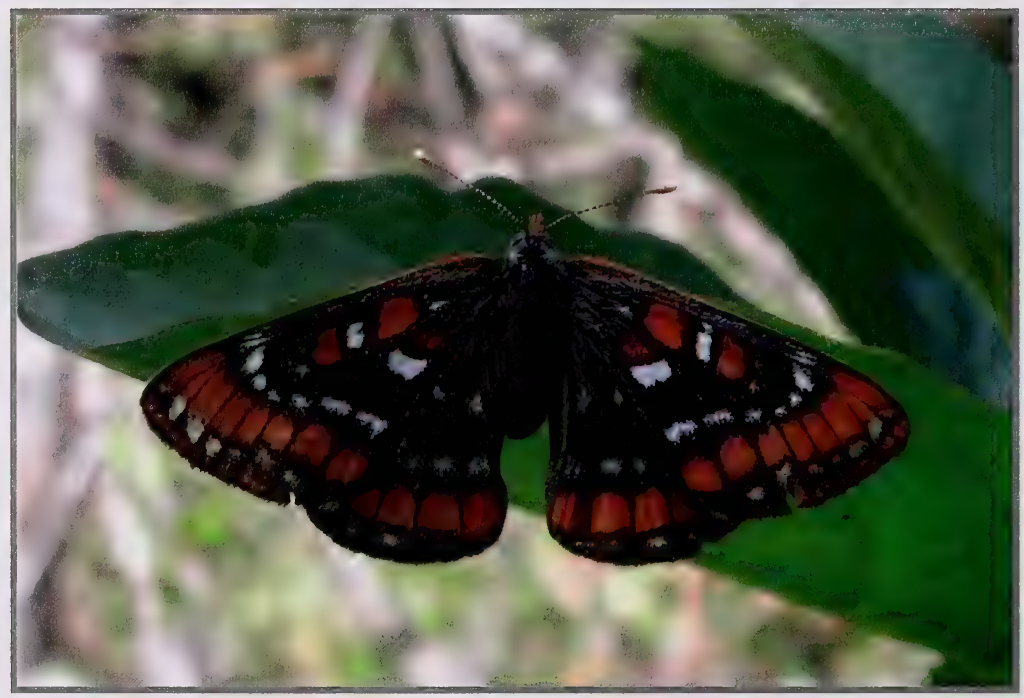

The prediapause larvae feed only on the epidermis and parenchyma of the leaves, leaving behind the network of veins. Over time the feeding web increases in size through inclusion of lower leaves. Feeding occurs during the day and the communal web can contain different aged larvae from egg masses laid by different females. The feeding web becomes the overwintering hibernaculum. These are well attached to shrub stems but most are dislodged by winter snow. Overwintering larvae can be second, third or fourth instar larvae.

Overwintering larvae terminate diapause soon after the snow melts and begin feeding on newly formed buds of honeysuckle. They bore holes into the larger apical buds and entirely consume the smaller axillary buds. Some postdiapause larvae disperse and will also feed on other plants in the genera Castilleja, Pedicularis and Valeriana. All of these plants contain iridoid glycosides which are sequestered as defensive chemicals by the larvae (Bowers and Williams 1995). 
Larvae normally move away from the host honeysuckle shrubs before pupating and usually pupate within $50 \mathrm{~cm}$ of the ground. Pupation normally lasts three weeks, after which the adults emerge. Adults typically fly for about a four week period in a given location; earlier in the season at lower elevation and warmer sites but later at higher elevation and cooler sites. As is the norm in butterflies, the males emerge earlier in the season and the male to female ratio declines gradually during the flight season. Males are reported to fly earlier in the day than females and also in relatively greater abundance on cloudy days.

\section{Figure 7. Larval hibernaculum. E. Williams photo}

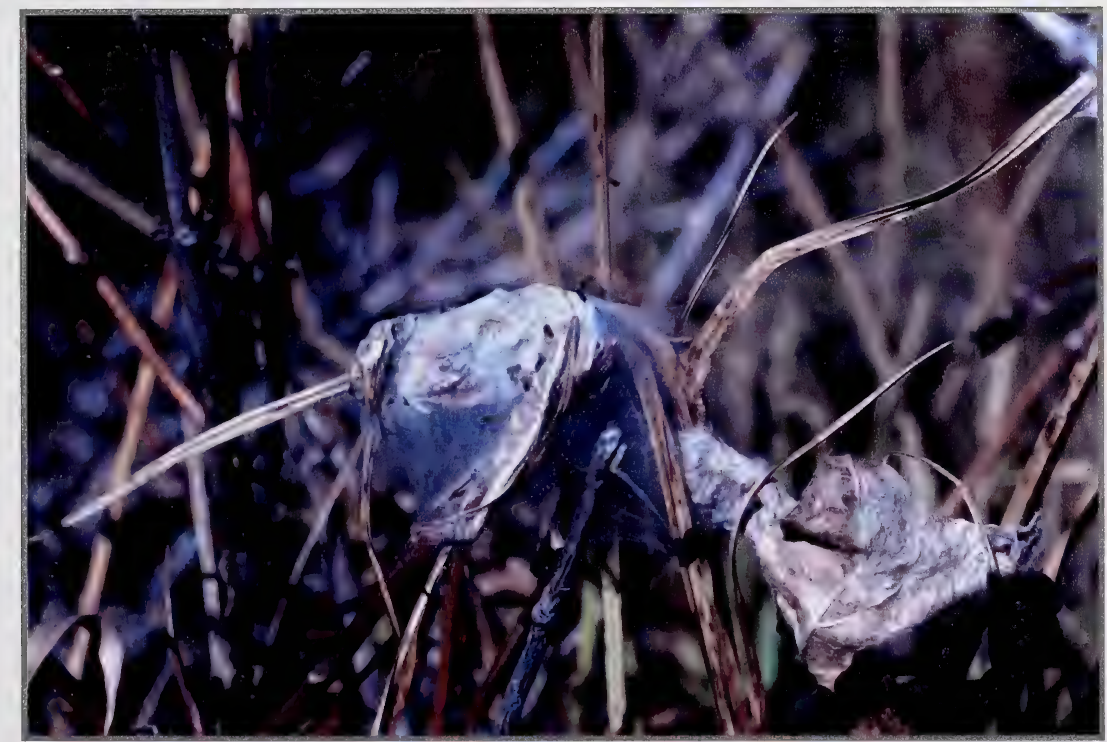

The adults are reported to spend much of the day sunning near the ends of branches high in coniferous trees. Adults perch overnight in trees and mating also occurs in the trees. Males apparently fly through the habitat more than females while females fly down to nectar more frequently although both males and females take nectar from available flowers, which are normally in ample supply in occupied habitat patches. Occasional puddling is reported in the literature and adults spend the nights in trees at least $3 \mathrm{~m}$ tall. Adult flight period likely varies from one year to the next as determined by weather in any given year. Adult flight dates in Alberta are from 16 June to 7 August (Bird et al. 1995). A variety of plant species are used as nectar sources. In 2004 I observed adults taking nectar at flowers of Senecio spp., dandelion (Taraxacum officinale), oxeye daisy (Chrysanthemum leucanthemum) and white geranium (Geranium richardsonii)

My observations and those shared by others with respect to Alberta populations support literature information, which is mostly based on USA populations. Detailed comparative studies have not been conducted but one apparent difference in Alberta populations is that of more active puddling by males. In 2004 I found that these butterflies are quite docile, both when taking nectar at flowers and also when taking salts and moisture from 
damp road surfaces adjacent puddles. To my surprise I found the males so docile and attracted to salt in the heat of the day that I had one individual taking salt from my arm and two more taking salt from my hat.

Figure 8. Male taking salt and water on damp road surface. This common behavior in male butterflies is called puddling. $\mathbf{N}$. Kondla photo

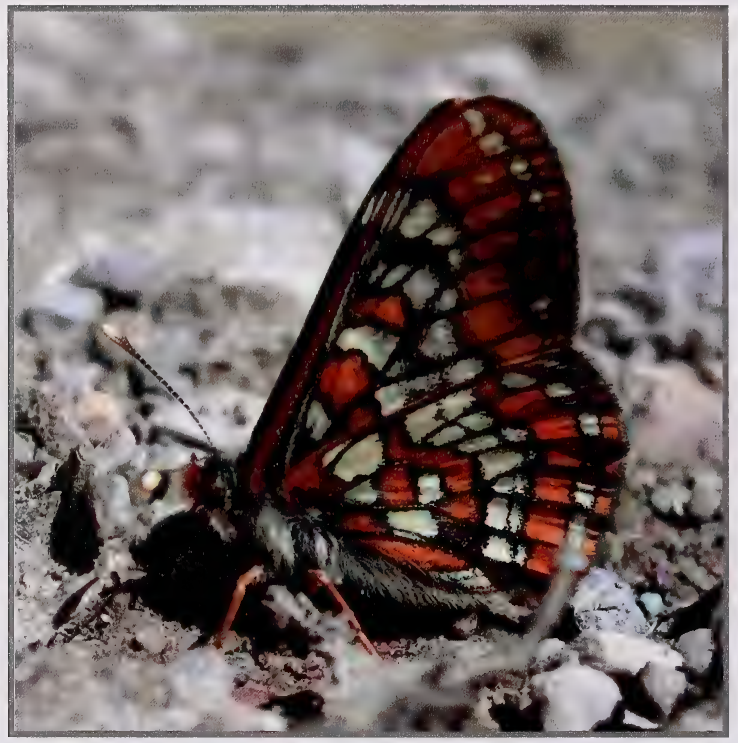

Brief habitat descriptions have been provided in butterfly books: Bird et al. (1995) mountain meadows and clearings; Guppy and Shepard (2001) - open riparian situations; Layberry et al. (1998) - moist meadows, usually near streams in mountain valleys, Ferris and Brown (1981) - moist meadows, especially along small streams, Opler (1999) openings and meadows in moist valleys in conifer forests.

Williams (1988) compared the habitat characteristics of 15 sites occupied by Gillett's Checkerspot in Alberta, Idaho, Montana and Wyoming. He found the following:

- All occupied sites were wet, with most having a small stream flowing through the habitat patch although several were marshy without obvious flowing water,

- There appears to be a correlation between colony size and nectar abundance,

- Larval food plant (honeysuckle) abundance did not correlate directly with population size,

- Most sites were disturbed, with fire being the prevailing natural disturbance source, the few sites not showing disturbance were on the edges of wet meadows,

- Occupied sites were at lower elevations at higher latitudes,

- Habitats at higher latitudes often have a southern exposure.

Debinski (1999) considered Gillett's Checkerspot as a habitat specialist and found it associated with wet meadows in the Greater Yellowstone Ecosystem. However it should be noted that study methodology confined butterfly sampling to meadows only. It should 
also be noted that previous reports of this butterfly being a meadow species might be a matter of differing concepts of what is and is not a meadow.

My observations in 2004, supplemented by past personal observations and information provided by other observers, indicate that the species is not a meadow butterfly in Alberta. The word meadow is normally used to describe a non-wetland grassy or herbaceous plant community without woody vegetation or with very limited woody vegetation. Such habitat, by itself, is unsuitable to sustain a population of Gillett's Checkerspot. The two key habitat ingredients of trees for mating and roosting, in proximity to non-shaded honeysuckle for egg laying and immature stages are necessary to sustain a population. Meadow habitat in proximity to these habitat attributes will be used as nectar sources by adults and if the meadows happen to contain some scattered honeysuckle plants, these will also be used as oviposition sites. But the predominant habitats in Alberta are otherwise, with breeding sites often being located in and adjacent to habitats that would qualify as fens in accordance with the Canadian Wetland Classification System (Warner and Rubec 1997).

Along the upper Oldman River the habitat consists of low shrub fens and sedge fens with open canopy bog borders. Honeysuckle plants were more abundant along the fen edges but some plants were also noted in less wet microsites in the open shrub fens. In contrast to more southern locations where the honeysuckle plants tend to be large and tall (Williams 1988); the Oldman River area plants are small and short (less than 1 metre).

The species has been found in the past adjacent Racehorse Creek campground. A small meadow is present but the honeysuckle plants grow in small fen patches and moist areas among the pine forest in the valley bottom adjacent the creek. At Livingstone Falls the habitat consists of small fens, shrub carr patches and very small pine forest openings where the requisite honeysuckle grows. Egg masses were found in 2004 near secondary highway 940 in a small habitat patch consisting of a fen/treed bog wetland complex adjacent a small stream and dry meadow.

North of the SHARP area C. Schmidt (pers. comm.) has found E. gillettii in a moist natural clearing resulting from a forest fire and also in a logged area. I. Gardiner (pers. comm.) has also found the species in a natural moist valley bottom opening undergoing natural succession to forest habitat.

West of Carbondale Hill I found adults active in a shrubby fen surrounded by coniferous forest. Along the upper Carbondale River adults were found in riparian forest along an old road and in an adjacent logged area. Egg masses were found to confirm breeding in the cutblock. Two females were found moving along a small tributary stream without any honeysuckle in sight. T. Pike (pers. comm.) and I have in the past both noted a robust population in logged openings along the South Castle River valley in the vicinity of Scarp Creek.

In the Whitney Creek area, A. Colley (pers. comm.) has for several years noted E. gillettii along roads and power line clearings; often without honeysuckle in sight. Such sightings 
were often of individuals taking nectar at flowers. Field review in 2004 revealed that the species was breeding in small wet openings in swampy open canopy forest and also in logged areas. One logged area with egg masses was only one year old; indicating that the species readily uses human-created forest openings for breeding if they support honeysuckle.

Along the South Castle road, Colley and Kondla noted a robust population using the moist and mesic parts of a regenerating cutblock logged approximately 25 years ago. A number of egg masses were found to confirm breeding use of the cutblock. Honeysuckle was found to be abundant in the adjacent forest but no evidence of breeding use of these shaded plants was found; consistent with published information on this point. This cutblock is also used for cattle grazing. Adults were also found nearby in association with a spring fen. West of Beavermines Lake adults were found puddling on a forest road, flying actively through open canopy forest and breeding in a selectively logged forest on a stream floodplain. The nearest example of breeding in a meadow in Alberta that I am aware of is at Beavermines Lake where a few large honeysuckle plants, situated in very small and fairly dry meadow-like forest openings are regularly used for breeding.

So the habitats known to be used in Alberta are low to mid-elevation level or gently sloping areas where some honeysuckle grows in locations exposed to sunlight. In other words, the butterflies use situations where natural succession to closed canopy forest is slowed due to edaphic conditions or interrupted by stochastic events. These situations are created partly through natural process resulting from groundwater discharge, wetland catchments, wildfire, insect and disease canopy removal, and fluvial geomorphology dynamics. Use of habitat created by Beaver activity has not yet been documented in Alberta but this is also a likely contributor to the creation of habitat suitable for $E$. gillettii. Portions of logged areas that support honeysuckle plants are also used for breeding and the enhanced wildflower blooms resulting from forest canopy removal are used by adults. In Alberta, Gillett's Checkerspot is a forest butterfly that is dependent on open canopy forest, small forest openings and forest edges where honeysuckle with sunny exposure is present for breeding. 
Figure 9. Breeding habitat of Gillett's Checkerspot at the edge of a cutblock harvested the previous year in the Whitney Creek area.

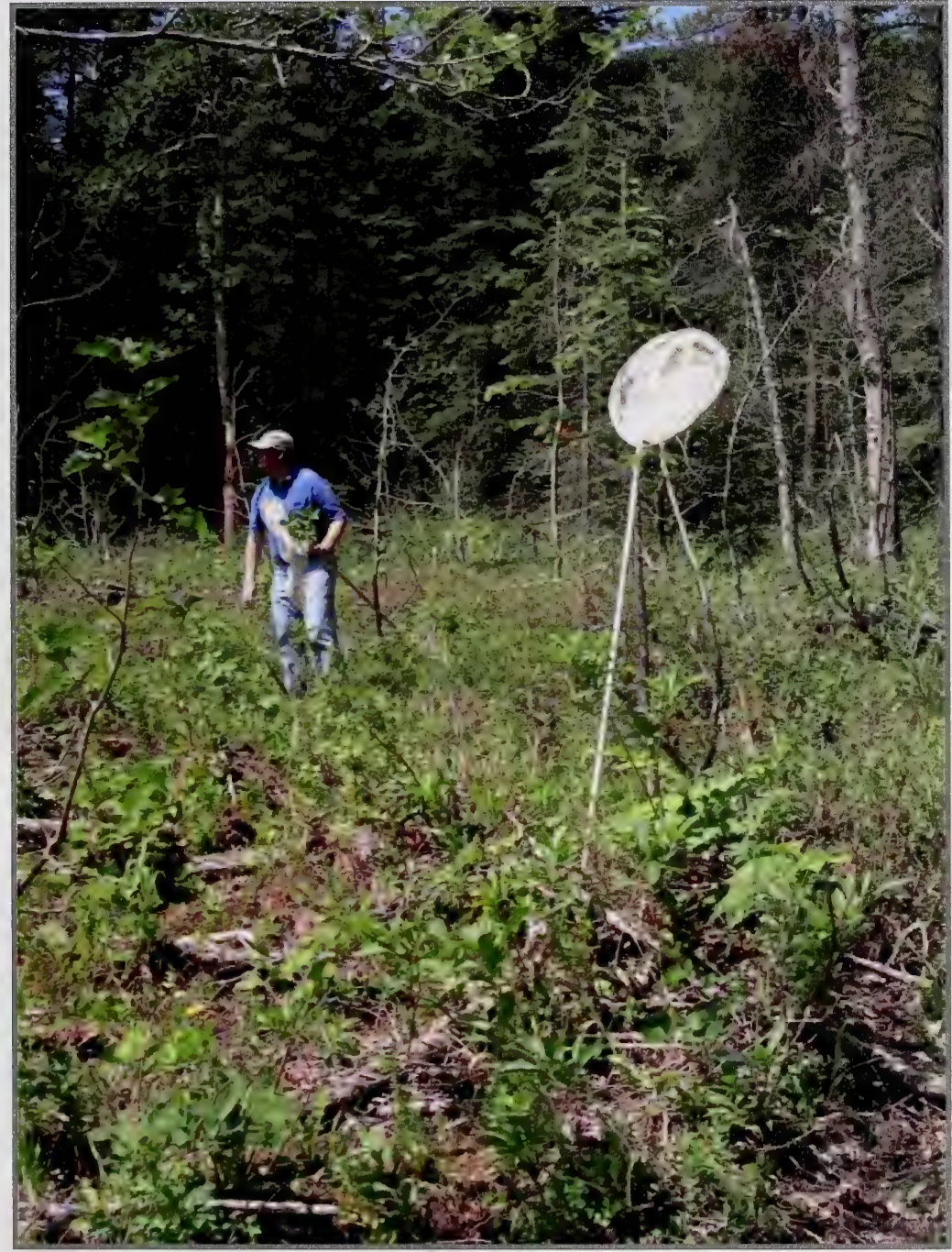


Figure 10. Breeding habitat in an older regenerating cutblock near Beavermines Lake.

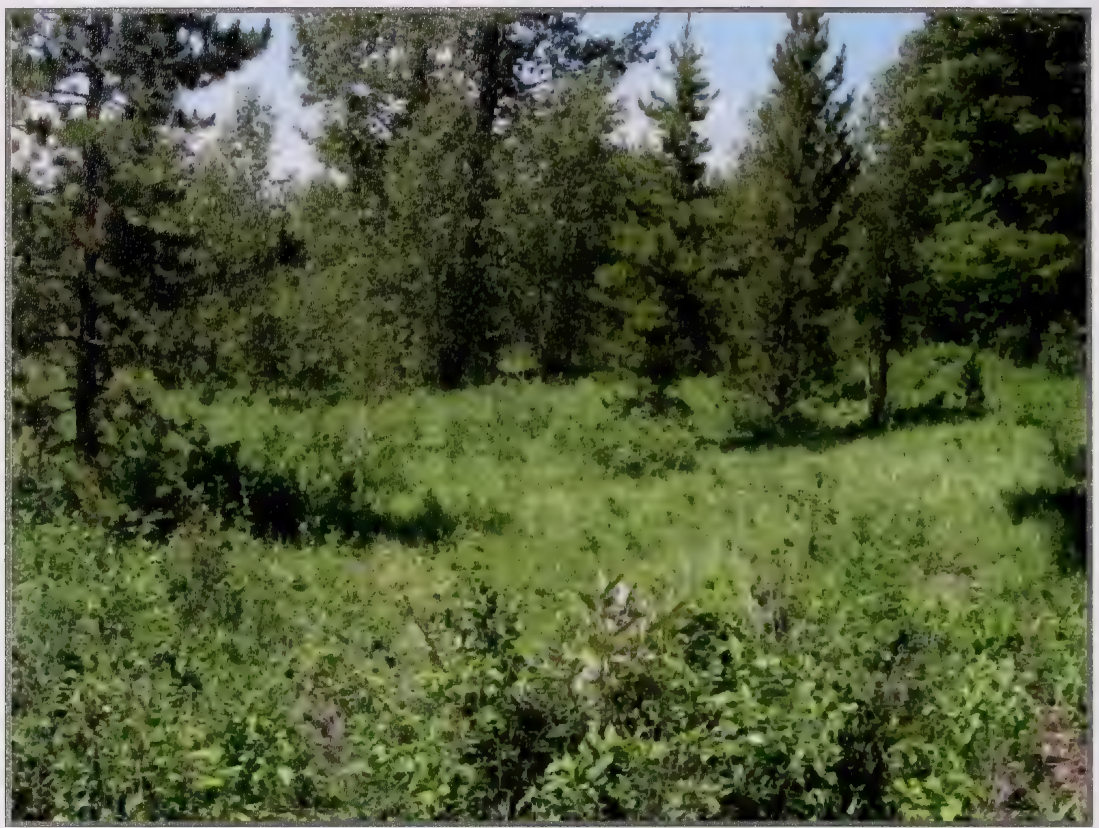

Figure 11. Natural breeding habitat in a small groundwater discharge site in the upper Carbondale River valley.

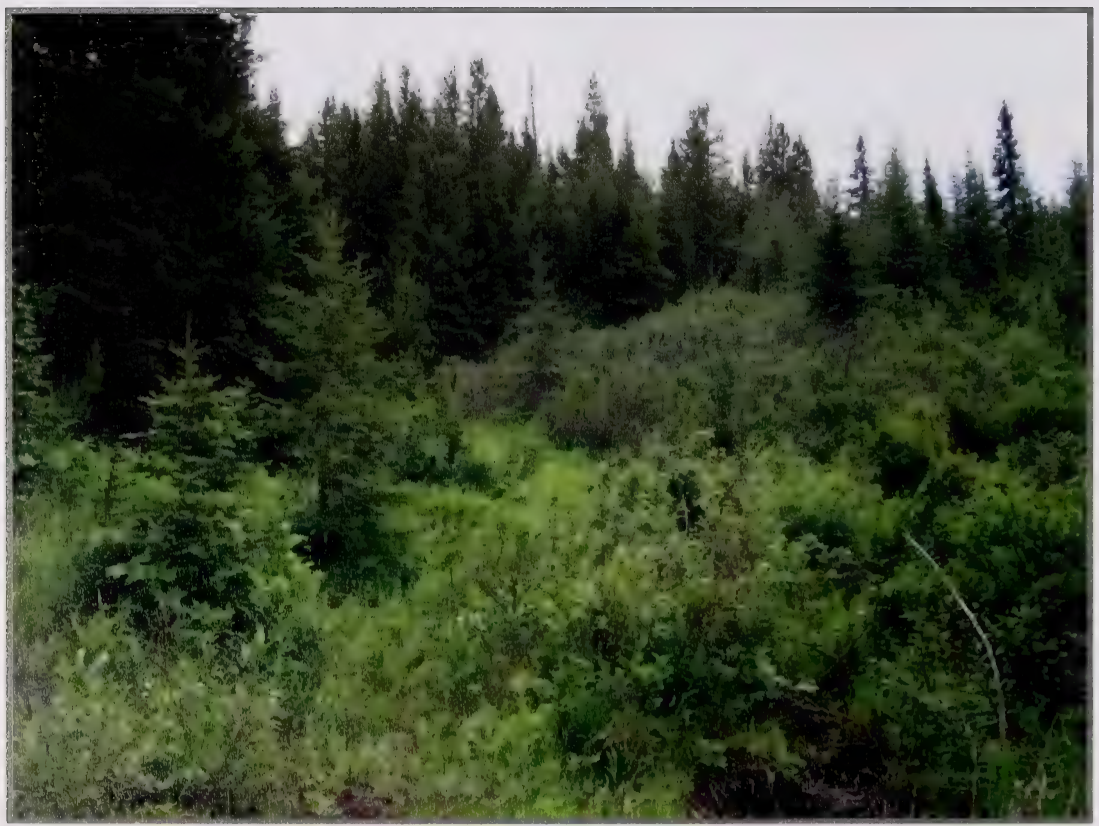


Figure 12. Natural breeding habitat in a fen/bog complex adjacent a valley bottom stream of the Livingstone River valley.

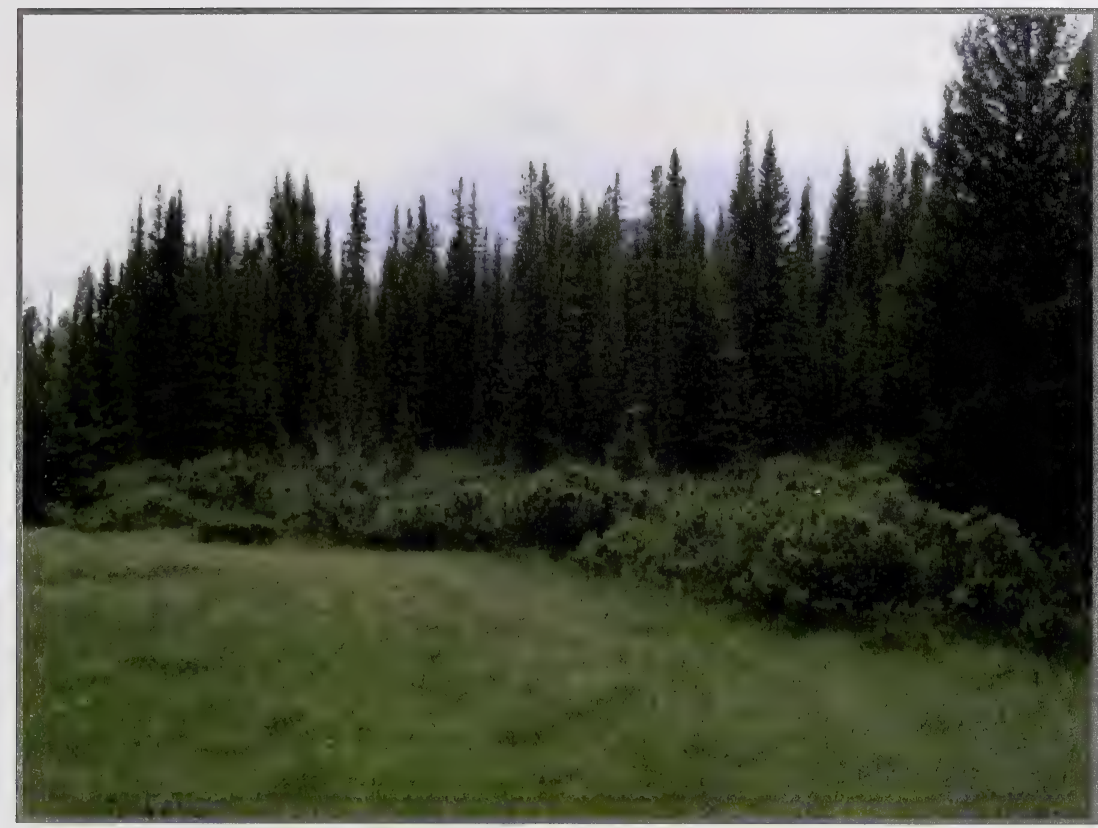

Figure 13. Breeding habitat at edge of sedge fen in upper Oldman River valley.

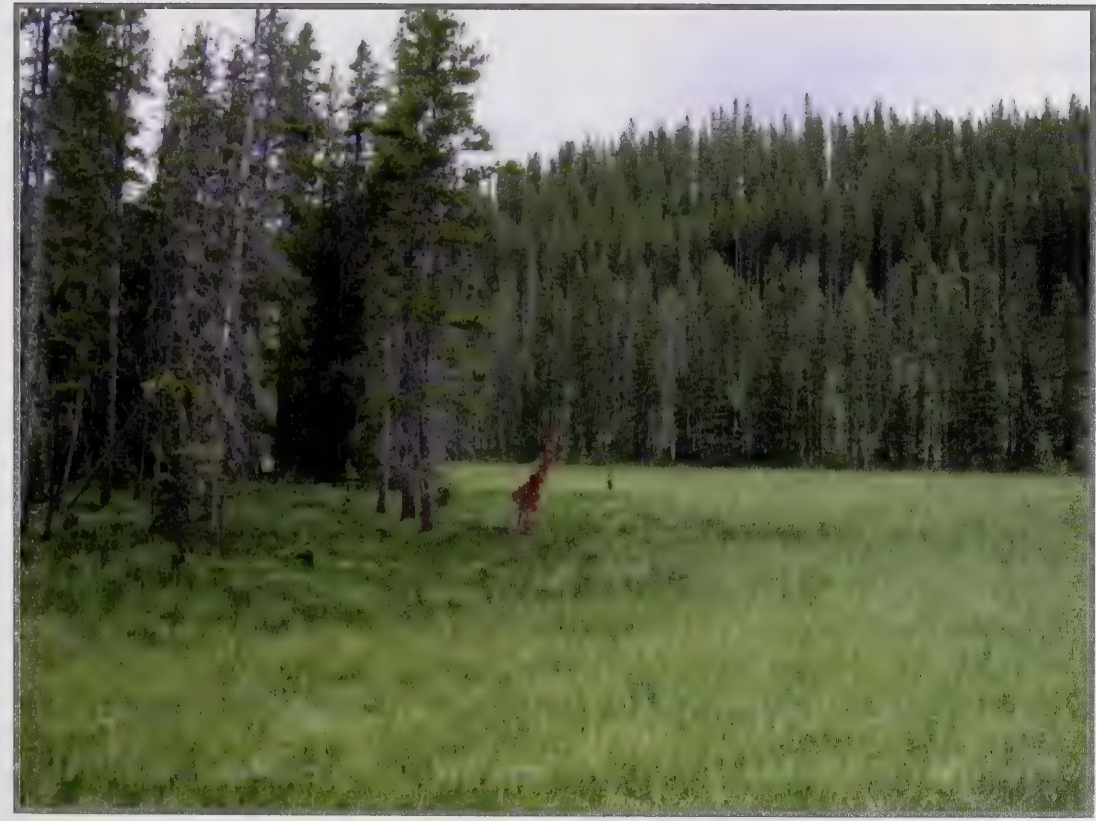




\section{Distribution and Abundance}

The global distribution of Gillett's Checkerspot is very limited $-0.07 \%$ of the global land area. The northern terminus of its known distribution is in southeastern British Columbia and southwestern Alberta. It is otherwise distributed in portions of Idaho, western Montana and western Wyoming. The southern terminus of its natural distribution is in southwestern Wyoming. A disjunct population has been established in Colorado by transplanting eggs and larvae (Holdren and Ehrlich 1981). From a Canadian perspective the range of the species is also extremely limited. A rough estimate is that the species range (extent of occurrence) in Canada is less than $0.2 \%$ of the national land base. Distribution records in Canada have previously been mapped by Layberry et al. (1998) and Guppy and Shepard (2001). Only two new locations have been discovered since 2001 in British Columbia, for a total of 4 known sites in that province. The species range in British Columbia is approximately $0.8 \%$ of the land area.

Alberta distribution has been mapped by Bird et al. (1995). Specific documented occurrence records are Bowman (1919), Kondla (2004a, b), Kondla and Bird (1979), and Pinel (1983). The species is essentially confined to the Rocky Mountains south of the Bow River; except for a conspicuously disjunct historical record from Nordegg (Bowman 1919). The species has not been recorded from Nordegg since then and review of Bowman collection data suggests that the historical Nordegg record may be based on a mislabeled specimen. The contemporary northern terminus of the distribution is unknown. Within the Alberta range I am presently aware of 30 populations. Figure 13 shows occurrence records known to me from the SHARP area. The range of the species in Alberta is approximately $1.9 \%$ of the provincial land area.

Within this very limited range, the species is even more limited to a small portion of the overall landscape (area of occupancy). Suitable habitat conditions as described in the previous section are confined to an unmeasured but clearly very small portion of the landscape. This is readily verified through simple observation of the extensive areas of the Alberta range which consist of rock, alpine tundra, dry meadows and dry grassy mountainsides within a matrix habitat of closed canopy lodgepole pine and spruce forest.

The most robust known metapopulation of the species in Alberta exists to the west and southwest of Beavermines Lake. A view of part of this area from a vantage point on Table Mountain is given in Figure 14. The same area is illustrated in a vertical aerial photograph (Figure 15). The recently harvested cutblock visible in this 1982 image is well along the path of forest regeneration and in 2004 moist and mesic areas with presence of bracted honeysuckle supported breeding by Gillett's Checkerspot. 
Figure 14. Distribution of Gillett's Checkerspot in the SHARP area. Black triangles are locations where the species has been found. Some triangles represent sightings of one or two individuals while others represent populations consisting of nearby sites.

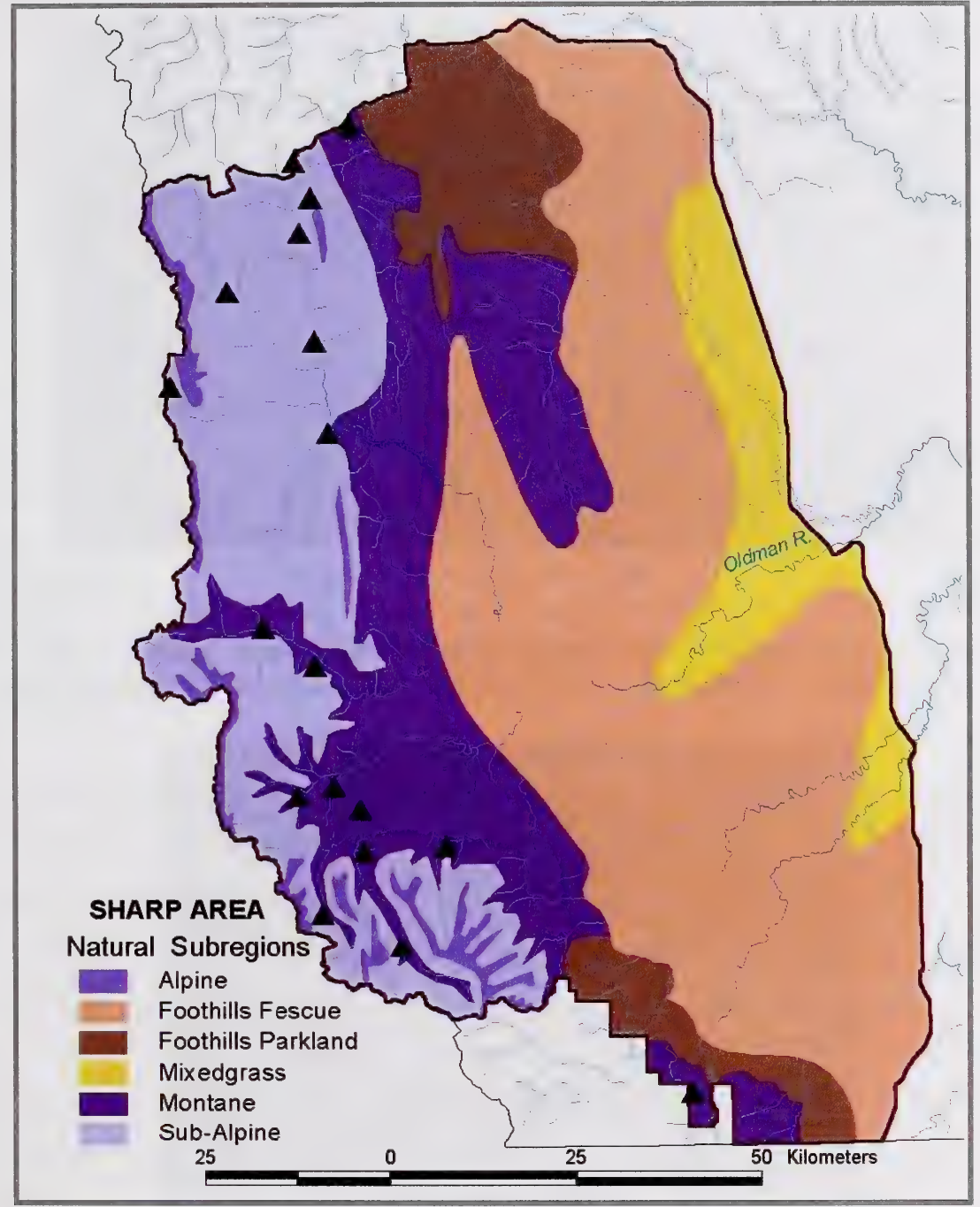

Another way to portray the limited distribution of Gillett's Checkerspot is in terms of presence/absence at sites examined. In 2004 I found the species present at only 10 of more than 75 sites surveyed. This is especially significant in light of the deliberate survey bias for sites that could plausibly support populations. A statistically random sampling of the landscape would certainly generate an even smaller resultant in terms of percent of sites being occupied. However there would be no point in searching alpine tundra, cliffs, talus slopes, avalanche tracks, dry montane grasslands and closed canopy coniferous forest for populations of this species since extensive field observation and structured 
Figure 15. Oblique view of the area west of Beavermines Lake. Gillett's Checkerspot occupies small and local suitable habitat patches within the forested landscape matrix of the image midground.

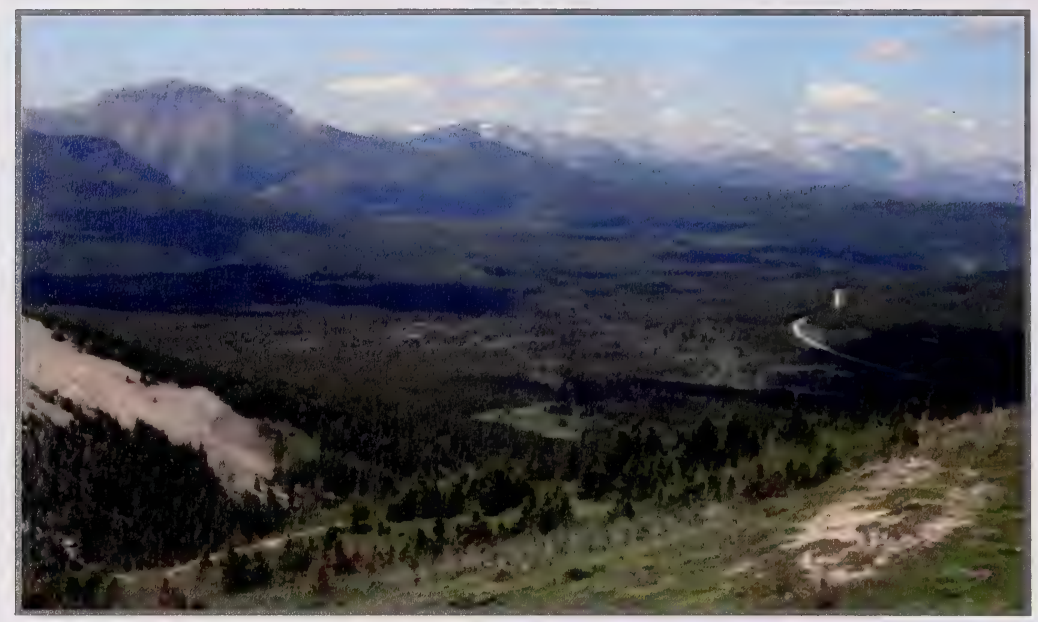

Figure 16. Aerial photograph (1982) of the area west of Beavermines Lake. This area supports a vigorous metapopulation. Note the recent cutblock in the lower area of the image.

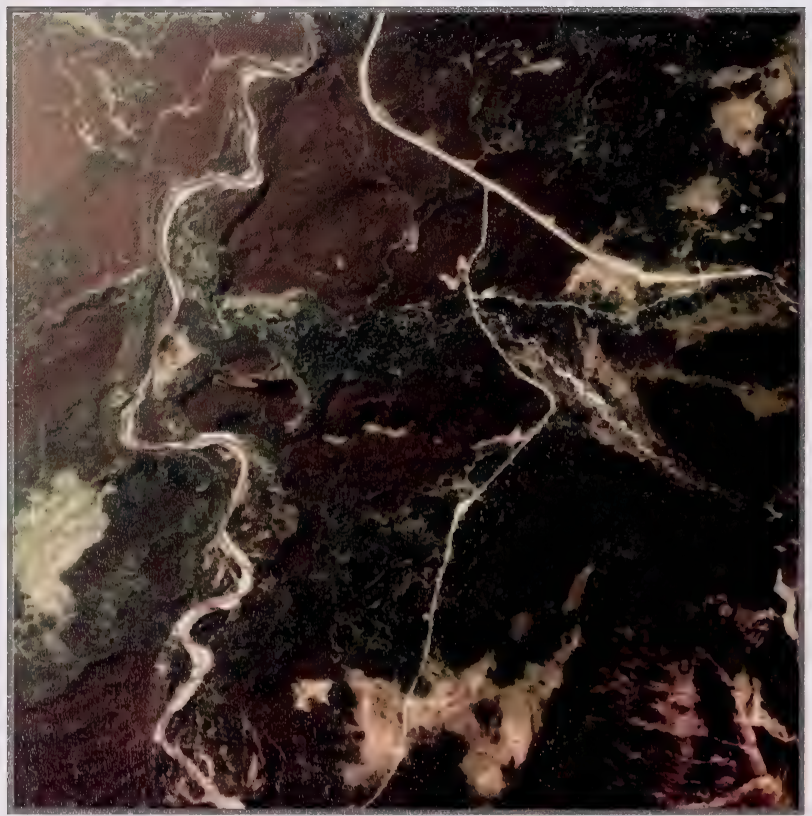

research has shown such habitats are not breeding habitat for the species. It is also worth noting that the Alberta portion of the species range has historically been visited by many qualified observers over many years during the adult flight window of the species. This 
level of survey intensity probably represents at least hundreds of field days with a resultant of 29 cumulative historical populations for the species. It is of course reasonable to think that additional occupied sites are present, since not all of the potential provincial range has been examined.

Even within the already exceedingly small portion of the landscape that qualifies as habitat for the species; the critical habitat component of honeysuckle plants in sunlight and near trees renders the breeding habitat, in a narrow sense, into a truly microscopic land base. Such small and scattered essential habitat components are vulnerable to destruction by one careless or uninformed movement by heavy equipment. The egg masses clustered on a few leaves of these few plants are ready victims of incidental carnivory by moose and livestock.

Williams (1988) conducted one day counts of adults, egg masses and larval webs at 15 sites, including two Alberta locations. He reported colony sizes (total adults and egg masses) of one to greater than 30. A population of one or a few adults is not reasonable so the low numbers may be an artifact of the data collection methodology and time available to examine sites. Debinski (1994) conducted a short mark-recapture study in Glacier National Park, Montana and calculated minimum population sizes of 142, 98, 56, and 28 adults at her study sites. Debinski also noted a low number of recaptures which suggests that the true population size could be much larger. Debinski also found that populations associated with linear corridor habitats were larger than those of meadow habitat patches.

Mark-recapture work has not been done on Alberta populations and metapopulations. Adult counts at the South Castle cutblock site suggest a minimum adult population of 100 at that site. Historical observation suggests similar abundance at one site further south in the South Castle River valley. R. Webster observed more than 100 adults in one hour at one habitat patch near Livingstone Falls in 1987. Observations at other Alberta locations are suggestive of smaller populations but there has been insufficient work to make confident statements about population and metapopulation size in the province. It is likely that populations experience lesser and greater population fluctuations in response to weather differences from one year to the next. Population extinction through natural succession and catastrophic stochastic weather events are also part of the population dynamics. It is also reasonable to think that populations will decline over time in occupied habitat patches undergoing succession to closed canopy forest, while populations adjacent or near newly created forest openings will increase in numbers for a period of time if the new opening contains the requisite honeysuckle plants. Debinski (1994) and Williams (1988) note major population fluctuations and the artificial Colorado population has recently experienced a population boom in comparison to historic levels (Boggs 2003). 


\section{Other Species}

I also watched for other species of conservation interest as determined through their status ranks as S1 to S3 per the Alberta Natural Heritage Information Centre. Very few were found, thus reinforcing their status as being of conservation interest. Pale Swallowtail (Papilio eurymedon) was seen along the South Castle road; one individual of Thicket Hairstreak (Mitoura spinetorum) and multiple individuals of Western Meadow Fritillary (Boloria epithore) were also noted along the South Castle road. The Western Meadow Fritillary was also found in the South Racehorse Creek area, upper Carbondale River and in a fen west of Carbondale Hill. A vagrant Arrowhead Blue (Glaucopsyche piasus) was found along the upper Carbondale River. Edward's Fritillary was noted in the Whitney Creek area. Location details are contained in Kondla (2004).

\section{Discussion}

From the perspective of biodiversity conservation the fundamental question to be addressed is whether or not Gillett's Checkerspot is a species of conservation concern in Alberta. Current ranking within the NatureServe framework is a global ranking of S2S3 with some contradictory information at the subnational level; probably due to lag times in updating web sites and because status ranking is an ongoing process. Status in Alberta is reported as S2. Status in BC is reported as S2 and S2S3. Montana status is reported as S2 and S3. No subnational rankings are available for Idaho and Wyoming. However a cursory examination of known distribution and ranking criteria suggests that ranks of S2 or S3 are reasonable for those states. The Colorado population probably warrants a status rank of S1 but this situation is unique because the population is an artifact of deliberate human interference through a scientific experiment. It raises interesting ethical, policy and operational questions with respect to how it should be handled from a conservation perspective. The General Status of Alberta Wild Species 2000 (http://www3.gov.ab.ca/srd/fw/speciesatrisk/general.html) ranks the species as sensitive. The main point is that knowledgeable sources list the species as being of conservation concern.

The species has not been assessed under the national Species At Risk Act. A brief review of assessment criteria under this regulatory mechanism suggests that the species could be ranked as Sensitive or possibly even Threatened if a formal status review were undertaken.

I consider Gillett's Checkerspot to be a legitimate species of conservation concern in Alberta for the following reasons:

- Very small global, national and provincial range (extent of occurrence),

- Even smaller area of occupied habitat patches (area of occupancy),

- Small populations, there are no known large populations,

- Dependence on one plant species growing in sunny locations in early successional plant communities that will disappear over time without intervention, 
- Presence of numerous human activities that could as easily harm the species as they could be helpful to the species if they were effectively planned and implemented.

Continued presence of populations and confirmed breeding in logged areas demonstrates that past land use activities have not driven the species to extinction. However, cutblocks will revert to closed canopy forest over time and a continued supply of appropriate successional habitat patches is needed to maintain the species in the landscape over time. It is possible and even probable that this can be achieved by accident, as it has in the past to a certain extent. It is easy to recognize the helpful results of land disturbing activities by the presence of breeding butterflies in those situations. But the historical information does not exist to determine if any populations have been extirpated as a result of fire suppression or land disturbing activities. I suggest that maintaining biodiversity by design and affirmative action is a better approach than maintaining biodiversity by accident.

Williams (1988) states that this species has the conservation advantage of its habitat being in mountainous areas that are not readily accessible and which have little immediate potential for human modification. My field work in the mountains of southwestern Alberta over 30 years tells me that this does not apply in Alberta. Although there have been actions taken to regulate vehicle access to some areas; on balance this portion of the province is easy to access and new access routes continue to be routinely created as part of economic activity. I have no doubt that a long history of fire suppression has resulted in the modification of habitat patches used by Gillett's Checkerspot. Direct habitat modification by human activity has also been a long term reality within the Alberta range of the species. Livestock grazing, forestry, oil and gas production, mining, pipe lines and power lines, and recreation have all left their mark on the landscape. These activities will continue to modify habitats of this area into the indefinite future.

Although a vigorous population was found in a cutblock grazed by livestock in 2004; another population appears to have been harmed by excessive livestock use. R. Webster (pers. comm.) reports a site near Livingstone Falls recreation area that supported more than 100 adults in lush habitat in 1987. In a visit to the same site in 2003 he observed only a few adults, few butterflies of other species and substantially damaged vegetation due to livestock grazing. The once abundant honeysuckle plants were dramatically reduced in abundance and those that survived had the critical (for egg laying) upper portions browsed off by livestock. A. Colley (pers.comm.) has also expressed concern about effects of livestock grazing on this species in the Beaver Mines Lake area.

Gillett's Checkerspot has been alleged to have low vagility (eg. Holdren and Ehrlich 1981) and poor dispersal ability (Debinski 1994). I can find no evidence to support this interpretation. Available information contradicts this possibility. Holdren and Ehrlich (1981) specifically noted seeing one adult "quite far from the original colony site". Boggs (2003) observed a female $6.5 \mathrm{~km}$ from the original Colorado release site, and still heading further away. The Colorado population experienced a 30 fold local range increase in 25 years. Debinski (1994) notes one Montana population distributed over a few kilometres. 
Debinski (1994) also reported a low number of recaptures. Since mark-recapture sampling measures patch residency; one reasonable interpretation of low recapture rate is that the majority of marked individuals have dispersed from the sampled habitat patch. It is also salient to consider that southwestern Alberta was under glacial ice as recently as 13,000 years ago. The Gillett's Checkerspot and all other native butterflies with alleged poor dispersal abilities have obviously moved into this region under their own wing power. Only a few alpine species may have survived the glaciation in situ on nunataks. The propensity of many individuals in butterfly populations to remain within a given habitat patch should not be confused with their demonstrated ability to move longer distances.

Gardiner (pers. comm.) observed an Alberta individual at mid elevation in a montane grassland about 150 metres from the nearest woody vegetation and with no suitable breeding habitat in sight. An apparently dispersing adult has been found at 2100 metres elevation on Tornado Pass (Kondla file information); far beyond the known breeding habitat of the species in Alberta. A worn female has also been found on Highwood Pass, again well outside the normal habitat. Gillett's Checkerspot is not a weak flyer. It is a robust butterfly that, from my observations, moves freely and rapidly through the environment when it chooses to do so. It can disappear from sight within seconds; in forest and in openings. Contrary to reports of it not using dry areas; I have observed these butterflies flying freely and breeding in dry areas. I have also observed dispersing females flying through a dry opening ca. $70 \mathrm{~m}$ in width; although movement was along the axis of a small stream at the bottom of an otherwise dry ravine. The existence of the species in a dynamic environment suggests that its flight and dispersal abilities are sufficient to maintain populations across the landscape.

\section{Management Guidelines}

Prevailing resource management thought (see Lee and Smith 2003 for a review) with respect to riparian areas is that disturbance should be minimized. While this is a reasonable management policy in general; it is counterproductive to maintenance or creation of vigorous populations of Gillett's Checkerspot and other species that require habitat attributes other than closed canopy forest. A closed canopy forest in riparian situations will not be helpful for this butterfly species. Unavoidable canopy removal for industrial activities can be used to create breeding habitat for Gillett's Checkerspot. In some cases active manipulation may be desirable to create some structural vegetation diversity along riparian corridors. Maximum biodiversity is created in stream corridor situations by managing for microhabitat diversity. A continuous corridor of mature and old closed canopy forest will in many cases be as undesirable as a continuous corridor of non-treed microhabitat.

Use of logged areas (cutblocks) presents an interesting policy and operational challenge to government and forestry companies. The policy issue is whether or not regenerating cutblocks which are supporting checkerspot populations should be managed in whole or in part to sustain said populations. In cases where decisions are made to attend to the 
needs of the checkerspot, the reality of financial costs and operational practicalities will need to be factored into revised management prescriptions and their implementation.

This species can easily co-exist with human economic activity. The survival needs of the species can be met without significant impact on resource use and development.

Awareness of basic species needs and willingness to incorporate these needs into existing decision-making processes will ensure that the species persists at reasonable population levels rather than struggling to survive by accident. Present information suggests that its survival needs are met by ensuring retention of honeysuckle plants in openings with some trees for roosting and mating in the near vicinity. The minimum number of adjacent trees is unknown at this time. My best guess is to manage for continued presence of at least 40 $\%$ original canopy cover adjacent to honeysuckle plants used for breeding. This still allows for substantial timber harvesting. In situations where there are no other competing biodiversity interests of comparable importance; clearcutting of small patches to encourage honeysuckle breeding sites and retention of roosting tree patches would be a reasonable approach.

Suggested strategic management guidelines are:

- Conduct and support further inventory to identify extant populations in natural habitats. Identification of the northern terminus of the Alberta range is of particular interest. Candidate habitat patches are readily identifiable from aerial photography,

- Conduct field surveys of cutblocks to identify those that have created habitat for Gillett's Checkerspot,

- Gillett's Checkerspot should be routinely included as one of the species at risk to be included in environmental screening, impact assessment, development planning and mitigation planning for all land-disturbing activities within the Alberta range. Regulation of livestock grazing on public lands should not be exempt from this,

- Government should review existing riparian management guidelines to ensure that they do not completely favor old seral stage species at the expense of early seral stage species,

- Government and industry should adopt a policy and practice of "designed enhancement" in cases where disturbance of checkerspot habitat cannot reasonably be avoided,

- Biologists and naturalists who encounter this species, while on the job or engaged in recreation, should record basic information and provide this to the Alberta Natural Heritage Information Centre,

- Both government and industry should be more aggressive and supportive in encouraging biologists, naturalists, forestry workers and range management/livestock management workers to be on the watch for (and report) presence of this and other species at risk. Volunteer work to enhance information could be encouraged with financial assistance for travel expenses,

- Support research to clarify requirements for tree retention and livestock grazing levels that will not materially harm populations, 
- Allocation of scarce management resources towards larger and more stable populations is suggested as a cost effective extinction risk abatement approach. A stochastic winking patch model likely has utility in dealing with this species (Etienne and Heesterbeek 2001).

Operational Guidelines

Generic guidelines that will help this species are simple:

- Determine if the species is or is likely to be present in an area intended for other natural resource uses or infrastructure development,

- Avoid locating uses and structures where they will destroy honeysuckle plants growing in forest openings near trees,

- Ensure that trees are left near locations where honeysuckle is growing in sunny locations,

- Develop and implement site specific mitigation measures where avoidance is not possible,

- Consider forest harvesting modification to enhance or create checkerspot breeding habitat. Designed removal of small numbers of trees at the periphery of cutblocks can be as helpful as retention of small treed patches within cutblock boundaries. 


\section{Literature Cited}

Bird, C.D., G.J. Hilchie, N.G. Kondla, E.M. Pike and F.A. Sperling. 1995. Alberta Butterflies. Provincial Museum of Alberta. 349 pp.

Bowers, M.D. and E.H. Williams. 1995. Variable chemical defence in the checkerspot butterfly Euphydryas gillettii (Lepidoptera:Nymphalidae). Ecological Entomology 20:208-212.

Bowman, K. 1919. Annotated checklist of the macrolepidoptera of Alberta. Alberta. Natural History Society, Red Deer 16p.

Brussard, P.F., P.R. Ehrlich, D.D. Murphy, B.A. Wilcox and J. Wright. 1985. Genetic distances and the taxonomy of checkerspot butterflies (Nymphalidae: Nymphalinae). Journal of the Kansas Entomological Society 58:403-412.

Comstock, J.A. 1940. Notes on the early stages of Euphydryas gillettii Barnes. Bulletin of the Southern California Academy of Science 39:111-113.

Debinski, D.M. 1994. Genetic diversity assessment in a metapopulation of the butterfly Euphydryas gillettii. Biological Conservation 70:25-31.

Debinski, D.M., K. Kindscher and M.E. Jakubauskas. 1999. A remote sensing and GISbased model of habitats and biodiversity in the Greater Yellowstone Ecosystem. International Journal of Remote Sensing 20: 3281-3291.

Etienne, R.S. and J.A. Heesterbeek. 2001. Rules of thumb for conservation of metapopulations based on a stochastic winking patch model. American Naturalist 158:389-407.

Ferris, C.D. and F.M. Brown. 1981. (Editors) Butterflies of the Rocky Mountain States. University of Oklahoma Press, Norman $442 \mathrm{p}$.

Guppy, C.S. and N.G. Kondla. 2000. Status of the butterflies and skippers of British Columbia for the National Accord for the Protection of Species at Risk. Prepared for Conservation Data Centre, Ministry of Environment, Lands and Parks. 87 pp. + MS Excell spreadsheet.

Guppy, C.S., J.H. Shepard and N.G. Kondla. 1994. Butterflies of conservation concern in British Columbia. Canadian Field Naturalist 108:31-40.

Higgins, L.G. 1978. A revision of the genus Euphydryas Scudder (Lepidoptera: Nymphalidae). Entomologists' Gazette 29:109-115.

Holdren, C.E. and P.R. Ehrlich. 1981. Long range dispersal in checkerspot butterflies: transplant experiments with E. gillettii. Oecologia 50:125-129.

Kondla, N.G. 2004. Conservation overview of butterflies in the southern headwaters at risk (SHARP) area. Alberta Fish and Wildlife, Alberta Species at Risk Report No. 80. 40 pp. http://www3.gov.ab.ca/srd/fw/speciesatrisk/pdf/SAR 80.pdf

Kondla, N.G. 2004a. Field report for 2004 Gillett's Checkerspot survey. File report prepared for Alberta Fish and Wildlife. $21 \mathrm{pp}$

Kondla, N.G. 2004b. Waterton Lakes National Park Gillett's Checkerspot survey. Prepared for Parks Canada. 9 pp.

Kondla, N.G. and C.D. Bird. 1979. The skippers and butterflies of Kananaskis Provincial Park, Alberta. Blue Jay 37:73-85.

Kondla, N.G., C.S. Guppy and J.H. Shepard. 2000. Butterflies of conservation interest in Alberta, British Columbia, and Yukon. Pp. 95-100 in Darling, L.M. (ed.).

Proceedings of a Conference on the Biology and Management of Species and 
Habitats at Risk. Volume 1. BC Ministry of Environment, Lands and Parks and University College of the Caribou. $490 \mathrm{pp}$

Layberry, R.A., P.W. Hall and J.D. Lafontaine. 1998. The Butterflies of Canada. University of Toronto Press. $280 \mathrm{pp}$.

Lee, P. and C. Smyth. 2003. Riparian forest management: paradigms for ecological management and practices in Alberta. Report produced by the Alberta Research Council (Vegreville, Alberta) and the Alberta Conservation Association (Edmonton, Alberta) for the Northern Watershed Project Stakeholder Committee. Northern Watershed Project Final Report No.1. 117 pp.

Miller, L.D. and F.M. Brown. 1981. A Catalogue/Checklist of the Butterflies of America North of Mexico. Memoir no. 2. The Lepidopterists' Society 280 p. Opler, P.A. 1999. A Field Guide to Western Butterflies. Houghton Mifflin Company, New York. 540 pp.

Pinel, H.W. 1983. Skippers and butterflies of the Indian Grave Campground area, Alberta. Blue Jay 41:71-77.

Tolman, T. 1997. Collins Field Guide Butterflies of Britain and Europe.

HarperCollinsPublishers Ltd., London. 320 pp.

Warner, B.G. and C.D. Rubec (eds.). 1997. The Canadian Wetland Classification System. University of Waterloo, Ontario. $68 \mathrm{pp}$.

Williams, E.H. 1981. Thermal influences on oviposition in the montane butterfly Euphydryas gillettii. Oecologia 50:342-346.

Williams, E.H. 1988. Habitat and range of Euphydryas gillettii (Nymphalidae). Journal of the Lepidopterists' Society 42:37-45.

Williams, E.H. 1990. Dietary breadth in Euphydryas gillettii (Nymphalidae). Journal of the Lepidopterists' Society 41:131-140.

Williams, E.H. 1995. Fire-burned habitat and reintroductions of the butterfly Euphydryas gillettii (Nymphalidae). Journal of the Lepidopterists' Society 49:183-191.

Williams, E.H. 2001. Gillett's Checkerspot: life in a mountain meadow. American Butterflies 9(2):6-13.

Williams, E.H. and M.D. Bowers. 1987. Factors affecting host-plant use by the montane butterfly Euphydryas gillettii (Nymphalidae). American Midland Naturalist 118:153161.

Williams, E.H., C.E. Holdren and P.R. Ehrlich. 1984. The life history and ecology of Euphydryas gillettii Barnes (Nymphalidae). Journal of the Lepidopterists' Society 38:1-12.

Zimmermann, M., N. Wahlberg and H. Descimon. 2000. Phylogeny of Euphydryas checkerspot butterflies (Lepidoptera:Nymphalidae) based on mitochondrial DNA sequence data. Annales of the Entomological Society of America 93:347-355.

Zirlin, H. 2001. Occam's razor: for whom was Gillett's Checkerspot named ?. American Butterflies 9(2):42-47. 

Library and Archives Canada Bibliotheque et Archives Canada

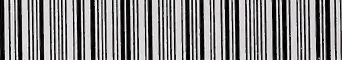

33286532173040 